\title{
港湾における浮体構造施設の現況と展望
}

\author{
運輸省 港湾技術研究所 正会員 上田 茂 \\ 運輸省 港湾局 技術課 正会員 吉 本 靖 俊 \\ (財) 沿岸開発研究也夘- 正会員 中田博 昭
}

1.はじめに

近年、快適な海辺の空間の創造を目的として、沿岸域の開発整備が積極的になされてきている。21世紀に向け ての沿岸域の開発整備の目標は、港湾を中核とする海辺の空間を市民生活の基盤として位置づけ、アメニティに 富んだ豊かでうるおいのある空間を形成することである。すなわち、従来は物資の流通の拠点あるいは交通の要 所としての性格が強調され、機能的に整備開発が行われてきた港湾空間の中に、市民生活に密接に関連する住宅、 ショッピングセンター、会議場、展示場、遊園地、公園、運動場、魚釣センター等の施設を有機的に配置し、新 たな市民生活基盤を形成するすのである。

このような目的意識を持って行われるプロジェクトにおける施設整備は、主に地方公共団体、当該地域に設立 される第三セクターまたは民間のデヴェロッパーなどによってなされている。

その中に、浮体構造物を利用した博物館、展示場、洋上レストラン、会議場などの施設が数多くみられる。横 浜港の山下公園前面の泊地に長期に係留され、展示場およびレストランとして利用されている『水川丸』に象徴 されるように、かつて、豪華客船や貨客船として一世を風麼した船舶を利用するすのす多い。別府港の『オリア ナ号』、東京港の南極観測船『宗谷』、名古屋港の南極観測船『ふじ』、鳥羽港の移民船『ぶらじる丸』、計画 中の青森港の青函連絡船『八甲田丸』および函館港の青函連絡船『摩周丸』などはその代表的なむのである。ま た、横浜博覧会に展示された六角形浮体を利用した『海のパビリオン』、境が浜マリンパークの『フローティン グアイランドおよび係留施設』などのように、利用目的に沿って、新たに建造されるすのむある。さらに、大水 深または軟弱地盤海域における係留施設としての大型浮体式係船岸、海洋性レクリエーションの需要に対応して マリーナなどの小型船用の浮体式係留施設などす、今後ますます数多く建造されることが予測される。

これらの浮体構造施設の計画および設計において特徵的なことは、第一に、浮体構造物を長期的に係留するこ とである。従来、港湾構造物の構造様式の主要なるのは重力式または杭式などの固定式であるので、浮体式構造 物のように波や風の作用によって動摇することはない。また、従来、係留船舶は荒天時においては港外に避泊し ているので、荒天時の係留を考慮して船舶および係留施設の設計がなされてはいない。したがって、我が国にお ける浮体構造物は台風等の低気圧による荒天時の強風および波浪の作用に対して、防げん材や係留索ならびにド ルフィンや係船柱などの係留系が十分な強度を有し、また、利用時において浮体構造物の動摇がその利用を妨げ ずかつ利用者の安全を損わない範囲にあるように、計画および設計しなければならない。これまで、浮体構造物 の計画に際しては、個々にその安全性を検討してきたが、このように類似の施設の整備計画が数多く出てきてい る現況に鑑みて、（財）沿岸開発技術研究センターでは浮体構造施設の計画および設計の問題点の抽出を行うと とむに、学識経験者による指導のるとに設計マニュアルの作成を行い、本年 7 月に発刊する予定である。第二は、 かつて客船などとして利用してきた船船等を一定の場所に係留し、不特定多数の人々の利用の用に供することで ある。そのため、安全、防火、避難などに関する設備規定および規格などは通常の船舶とは一部異なるむのが求 められることである。

本論文においては、これらの浮体構造施設の現況と展望を概括し、また、その安全性の検討における浮体構造 物設計マニュアルに従って要点を概説する。

\section{2. 浮体構造施設の現況}

\section{(1) 概要}

表一 1 はこれまでに設置された主要な浮体構造施設の概略を示したものである。要目の欄に12,000GTなどと表 示しているあのは、船舶を活用したあのである。用途はレストラン、展示場、博物館などが多いが、とくに船舶 を利用したものでは、客室、ブリッヂやエンジンルームなどの船内の設備、豪華な家具・調度類などを展示して いる。また、南極観測船の『宗谷』や『ふじ』では、船室や船内設備の展示のほかに、南極観測の意義、南極観 測の歴史、内外の探検隊の南極点踏破の経緯、観測資材などを展示していて、いわば南極博物館ともいえる。こ れらの浮体構造施設の立地場所は、これまではほとんどのむのが内湾や湖沼、また、松島などのように多くの島 で遮蔽され外洋の波が直接作用することのない静穏な海域である。すなわち、浮体構造物に作用する波力はさほ ど大きくはなく、また、台風時といえどす周囲の山などにより遮蔽されて比較的風当りむ強くない。しかしなが ら、この場合浮体構造施設のレストランなどからの海の眺望は、周辺の島や山そしてその周辺の海面などであっ 
てある程度限られている。しかし、オリアナ号のように遙か彼方の水平線が眺望できるほどに視界を大きくとる ように配置すると、瀬戸内海に立地するとはいえ再現期間における最大波が周期7.0s、波高3. 3m、また、平均風 速す33.9m/sなどとなるので、浮体構造施設の安全性からみて係留施設の設計が極めて重要になる。今日、市民 の海に対する要望が多様化してきているので、今後、このような立地条件の浮体構造施設の計画る多々あること と予測される。そこで、二三の浮体構造施設について規模、設計条件、係留系などについて概説する。写真 1 8 は浮体構造施設の事例である。

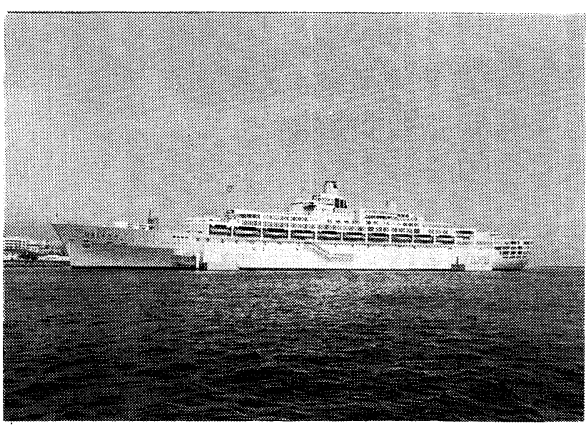

写真－1 オリアナ号 (別府港)

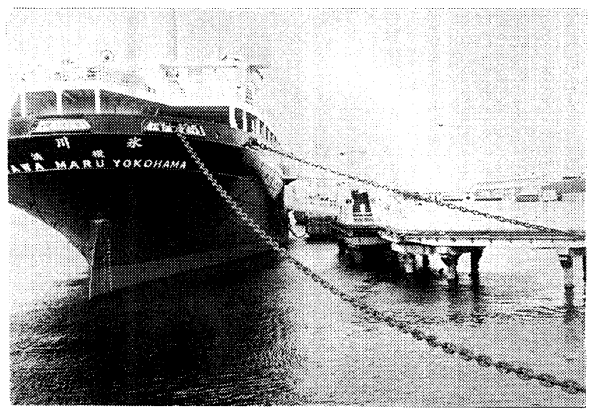

写真-3 水川丸（横泜港）

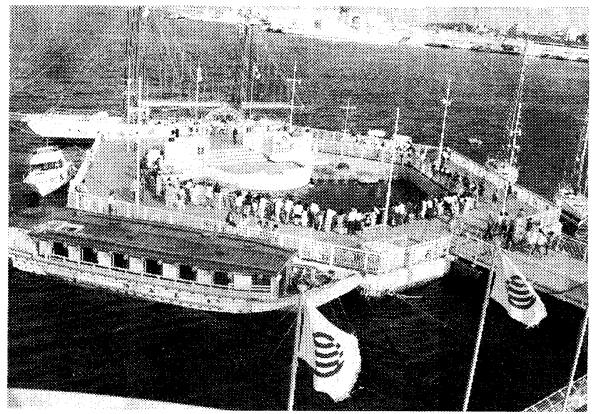

写真 -5 海のパピリオン（横浜博覧会）

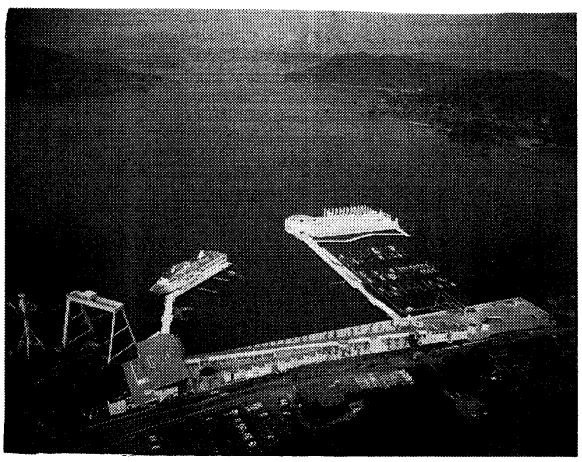

写真 -7 境ケ浜マリンパーク

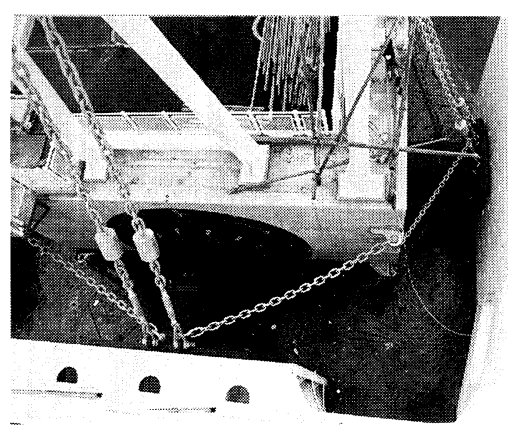

写真 -2 オリアナ号の係留施設

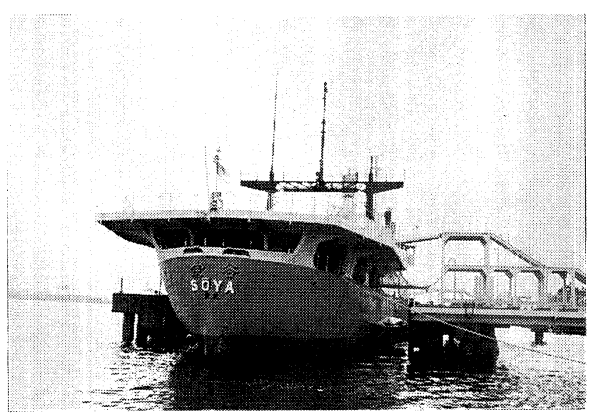

写真-4 宗谷（東京港）

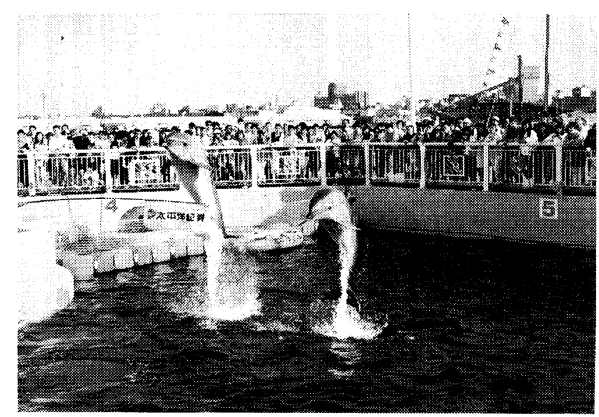

写真一 6 海のパビリオンにおけるショウ

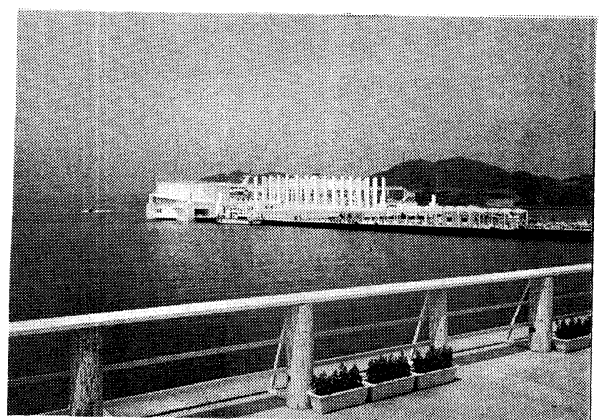

写真 -8 境ケ浜マリンパーク 
表一1これまでに設置された主要な浮体構造施設の一覧

\begin{tabular}{|c|c|c|c|c|c|c|}
\hline 番号 & 称 & 営業開始年 & 用 & 在 & 要 & 定 員 \\
\hline 1 & 水 川 丸 & 昭和 36 年 & レストラン・展示場 & 横浜市山下公園 & $12,000 \mathrm{GT}, 163 \mathrm{~m}$ & 331名 \\
\hline 2 & かなわ & 昭和 37 年 & レストラン（かき舟） & 広島市元安川 & $27 \mathrm{~m}$ & \\
\hline 3 & ひろしま & 昭和 40 年 & レストラン（かき舟） & 広島市元安川 & $21 \mathrm{~m}$ & \\
\hline 4 & (ショョ-ボート) & 昭和 44 年 & 劇 & 石川県片山津温泉 & $54 \mathrm{~m}$ & 459名 \\
\hline 5 & 砛シジ比阢 & 昭和 45 年 & ホ テ ル & 沼津市西浦 & $5,105 \mathrm{GT}, 127 \mathrm{~m}$ & 113名 \\
\hline 6 & 龍 鳳 丸 & 昭和48-49年 & レストラン & 宮城県宮城郡松島町 & $16 \mathrm{~m}$ & 24名 \\
\hline 7 & 鳳 凰 丸 & 昭和 $48-49$ 年 & レストラン & 宮城県宮城郡松島町 & $16 \mathrm{~m}$ & 56 名 \\
\hline 8 & ぶらじる丸 & 昭和 49 年 & レストラン・展示場 & 三重県鳥羽市 & $10,216 \mathrm{GT}, 156 \mathrm{~m}$ & 2,000名 \\
\hline 9 & アクアポリス & 昭和 50 年 & 展 示 場 & 沖縄県 & $104 \times 100 \times 32 \mathrm{~m}$ & \\
\hline 10 & 宮 & 昭和 51 年 & レストラン & 長野県野尻湖 & $25 \mathrm{~m}$ & 150名 \\
\hline 11 & 路 & 昭和 53 年 & レストラン & 三重県鳥羽市 & $180 \mathrm{GT}, 39 \mathrm{~m}$ & 102名 \\
\hline 12 & 宗 & 昭和 54 年 & 展 示 場 & 東京都品川区八潮 & $2,734 \mathrm{GT}, \quad 83 \mathrm{~m}$ & \\
\hline 13 & (海中展望船) & 昭和 57 年 & 遊泳魚観覧 & 熊本県天草郡 & $50 \mathrm{~m}$ & 1,500 名 \\
\hline 14 & まんぼう & 昭和 58 年 & レストラン & 佐賀県東松浦郡 & $22 m$ & 250名 \\
\hline 15 & サン 浦島 & 昭和 59 年 & レストラン & 三重県鳥羽市 & $350 \mathrm{GT}, 26 \mathrm{~m}$ & 160名 \\
\hline 16 & （水上レスラン） & 昭和 60 年 & レストラン & 岡山県玉野市 & $28 \mathrm{~m} \times 20 \mathrm{~m}$ & 100名 \\
\hline 17 & （浮き棧橋） & 昭和 60 年 & レストラン・展示場 & 北海道洞爺湖 & $28 \mathrm{~m}$ & 120名 \\
\hline 18 & 3 & 昭和 60 年 & 博 物 館 & 名古屋市 & $5,250 \mathrm{GT}, 100 \mathrm{~m}$ & 521名 \\
\hline 19 & 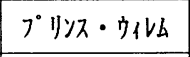 & 昭和 60 年 & 展 示 場 & 長䐀県西彼杵郡 & $1,460 \mathrm{GT}, \quad 73 \mathrm{~m}$ & 300 名 \\
\hline 20 & オリアナ号 & 昭和 62 年 & レストラン・展示場 & 別府市 & $41,920 \mathrm{GT}, 245 \mathrm{~m}$ & 6,650 名 \\
\hline 22 & 係留施設 & 昭和 63 年 & 係留施設 & 福島県猪苗代湖 & $12 \times 10.4 \times 2 \mathrm{~m}$ & \\
\hline 23 & 海のペビリオン & 平成 元 年 & 展 示 場 & 横浜博覧会会場 & $40 \times 34.6 \times 5 \mathrm{~m}$ & \\
\hline 24 & 境ヶ浜对パーク & 平成 元 年 & レストラン・展示場 & 尾道市浦䗁町 & $130 \times 40 \times 5 \mathrm{~m}$ & \\
\hline
\end{tabular}

注）定員の欄の空欄は不明

\section{(2) 主要な浮体構造施設の設計条件等}

ここでは、別府港の『オリアナ号』、名古屋港の南極観測船『ふじ』、東京港の南極観測船『宗谷』、青森港 の青函連絡船『八甲田丸』、境ヶ浜マリンパークの『フローティングアイランド』について、事業概要、設計条 件等について概略を示す。表一 2 は係船施設の計画条件および設計条件である。

設計においては、とくに、台風時の安全性について慎重な検討がなされている。その場合、まず、浮体構造施 設の耐用年数に対する所要の再現期間の風速を設定し、また、その条件に対応する浮体構造施設の設置海域の波 浪条件を求め、主として風と波との作用によって浮体構造施設に作用する外力、動摇および係留力を算定し、所 定の安全性を有する係留系の諸元を決定している。しかしながら、以下の諸点において、各施設ごとに検討の方 法が異なっている。すなわち、(1)風速の再現期間、(2)風速として平均風速または最大瞬間風速のいずれを用いる か、(3)変動風の取扱、(4)風と波との相互作用、(5)不規則波の取扱、(6)係留系の非線形性などである。これらにつ いては、のちに、浮体構造物技術マニュアルの節で述べる。

係留系に用いられている要素は、係留ドルフィン、ごむ防げん材、チェーン、アンカー、シンカー、係留索 (ワイヤロープ、織維索 : ナイロンロープ等) などである。これらのうち、ごむ防げん材および係留索はその変 位復元力特性が非線形であるので、風と波とが同時に作用する場合には定常力による変形と変動荷重による変形 とを十分に考慮して、係留系の適切な諸元を求める必要がある。

\section{（3）関連行政機関および関連法規等}

浮体構造物を係留して、博物館や観光施設として使用する場合の検討項目および必要な諸手続は以下に示すと おりである。ここで、担当行政機関とは、地方公共団体の担当部局を指すが、ここでは事例を示す。これらのう ち、浮体構造物の本体および係留施設の安全性に係わる検討項目については、港湾法、船舶安全法の適用を受け 


\section{表 -2 浮体構造施設の設計条件等}

\begin{tabular}{|c|c|c|c|c|c|}
\hline & オリアナ号 & ふ じ & 宗 谷 & 八甲田丸 & 境ケ浜マリッパーク \\
\hline 設計風速 & $\begin{array}{l}\quad 33.9 \mathrm{~m} / \mathrm{s} \\
50 \text { 年確率風速を } \\
\text { 海上風に補正 }\end{array}$ & $\begin{array}{l}\text { 常 時: } 16 \mathrm{~m} / \mathrm{s} \\
\text { 異常時: } 60 \mathrm{~m} / \mathrm{s}\end{array}$ & $\begin{array}{c}\text { 最大瞬間風速 } \\
50 \mathrm{~m} / \mathrm{s}\end{array}$ & \begin{tabular}{|c|}
$30 \mathrm{~m} / \mathrm{s}$ or $23 \mathrm{~m} / \mathrm{s}$ \\
$\mathrm{S}, \mathrm{W}, \mathrm{N}, \mathrm{E} \quad$ ESE, SSE \\
100 年再現期待値
\end{tabular} & $\begin{array}{c}28 \mathrm{~m} / \mathrm{s} \\
100 \text { 年再現期待値 }\end{array}$ \\
\hline 設 計 波 & $\begin{array}{rrr}\mathrm{T}_{1 / 3} & \mathrm{H}_{1 / 3} \\
\text { NNE } & 6.0 \mathrm{~s}, & 2.1 \mathrm{~m} \\
\text { N E } & 7.0 \mathrm{~s}, & 2.5 \mathrm{~m} \\
\text { ENE } & 7.0 \mathrm{~s}, & 3.3 \mathrm{~m} \\
\text { E } & 7.0 \mathrm{~s}, & 3.3 \mathrm{~m} \\
\text { ESE } & 6.2 \mathrm{~s}, & 2.9 \mathrm{~m} \\
\text { S E } & 4.7 \mathrm{~s}, & 1.9 \mathrm{~m}\end{array}$ & $\begin{array}{rr}T_{1 / 3} & H_{1 / 3} \\
\text { 常 時: } 1.4 \mathrm{~s}, & 0.5 \mathrm{~m} \\
\text { 異常時: } 3.0 \mathrm{~s}, & 0.6 \mathrm{~m}\end{array}$ & $\begin{array}{l}\mathrm{T}_{1 / 3} \mathrm{H}_{1 / 3} \\
6.0 \mathrm{~s}, \quad 3.0 \mathrm{~m}\end{array}$ & 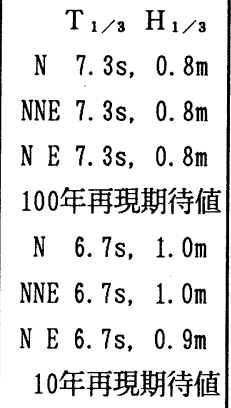 & $\begin{array}{l}\mathrm{T}_{1 / 3} \mathrm{H}_{1 / 3} \\
4.0 \mathrm{~s}, 1.5 \mathrm{~m}\end{array}$ \\
\hline 水平震度 & $\mathrm{K}_{\mathrm{h}}=0.1$ & $\mathrm{~K}_{\mathrm{n}}=0.2$ & $\mathrm{~K}_{\mathrm{h}}=0.2$ & & \\
\hline 潮位 & $\begin{array}{ll}\text { HHWL } & 3.40 \mathrm{~m} \\
\text { HWL } & 2.10 \mathrm{~m} \\
\text { LWL } & 0.00 \mathrm{~m} \\
\end{array}$ & $\begin{array}{ll}\text { HHWL } & 5.35 \mathrm{~m} \\
\text { HWL } & 2.60 \mathrm{~m} \\
\text { LWL } & 0.00 \mathrm{~m} \\
\end{array}$ & $\begin{array}{lr}\text { HHWL } & \mathrm{m} \\
\text { HWL } & \mathrm{m} \\
\text { LWL } & 0.00 \mathrm{~m} \\
\end{array}$ & $\begin{array}{ll}\text { HHWL } & 1.50 \mathrm{~m} \\
\text { HWL } & 0.80 \mathrm{~m} \\
\text { LWL } & 0.00 \mathrm{~m} \\
\end{array}$ & $\begin{array}{ll}\text { HHWL } & 4.95 \mathrm{~m} \\
\text { HWL } & 4.12 \mathrm{~m} \\
\text { LWL } & 0.00 \mathrm{~m}\end{array}$ \\
\hline $\begin{array}{l}\text { 係留施設 } \\
\text { の 様 式 }\end{array}$ & $\begin{array}{l}\text { ドルフィン } \\
\text { ごむ防げん材 }\end{array}$ & 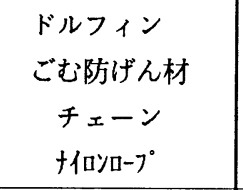 & $\begin{array}{l}\text { ドルフィン } \\
\text { ごむ防げん材 }\end{array}$ & 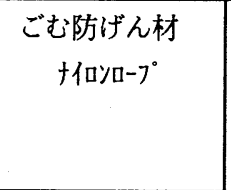 & $\begin{array}{l}\text { チェーン } \\
\text { シンカー }\end{array}$ \\
\hline $\begin{array}{l}\text { 係留施設 } \\
\text { の 諸 元 }\end{array}$ & $\begin{array}{c}\text { 定反力型 } \\
1,250 \mathrm{H} \sim 3,000 \mathrm{H}\end{array}$ & $\begin{array}{r}\text { 定反力型 } \\
300 \mathrm{H} \times 4,500 \mathrm{~L} \\
\text { チェ } \text {-ฯ } 58 \\
\text { †仕 } \phi 65 \\
\end{array}$ & $\begin{array}{c}\text { 定反力型 } \\
300 \mathrm{H} \times 2,500 \mathrm{~L}\end{array}$ & $\begin{array}{c}\text { 反力渐増型 } \\
2,500 \mathrm{H} \times 4,500 \mathrm{~L} \\
\text { 十仗 } \phi 75 \sim 80\end{array}$ & $\begin{array}{c}チ_{I}-\text { ソ } \\
2 \text { 種 } \phi 76 \\
3 \text { 種 } \phi 78\end{array}$ \\
\hline $\begin{array}{l}\text { 主要検討 } \\
\text { 項 目 }\end{array}$ & $\begin{array}{l}\text { 台風時の } \\
\text { 安全性 }\end{array}$ & $\begin{array}{c}\text { 小型船泊地 } \\
\text { との調整 }\end{array}$ & とくになし & $\begin{array}{l}\text { 台風時の } \\
\text { 安全性 }\end{array}$ & $\begin{array}{c}\text { 台風時の } \\
\text { 安全性 }\end{array}$ \\
\hline
\end{tabular}

る。安全性に係わる事項は、（財）沿岸開発技術研究センター、日本海事協会などに設けられた委員会において 検討されている。また、設置海域周辺の海上交通の安全性に係わる事項については、日本海難防止協会等に設け られた委員会において検討されている。

(1)営業活動

(2)空間利用

(3)関連交通

(4)構造物の安全性

(5)構造物の環境への影響 6)港湾関係の諸手続

(7)漁業関係者との調整 8)地元関係業界との調整 (9)消防防災対策

(10環境衛生対策
论株主構成、认需要予測、々採算性 々空間需要、乞船舶航行との関連（港湾課） 駐車場（港湾施設管理条令による許可 : 港湾課、都市計画決定 : 都市計画課） 々交通流（港湾内：港湾課、国道県道等、歩行者対策 : 都市計画課、県警） 污構造物自体の安全性（港湾法、船舶安全法 : 港湾課）、 污附設構造物への影響（港湾課）

分景観、公視界、它水産資源、污潮流 々水域専用許可（港湾法第37条第 1 項 : 港湾課） 海岸保全施設の占有（海岸法第7条、8条 : 港湾課) 々港湾施設使用許可（港湾施設管理条令臨港地区内の分区の構造物の規制） (都道府県、市町村) （都道府県、市町村） 污消防法（消防用設備等の設置維持義務、消防法第17条第1項 : 消防防災課） 们高圧ガス取締汰（汢第5条第1項2号による阡可又は同条第2愐第2号による届出： 消防防災課)

乞液化石油ガス取引適性化法 污食品衛生法（同法に基づく許可 : 薬務環境衛生課） 


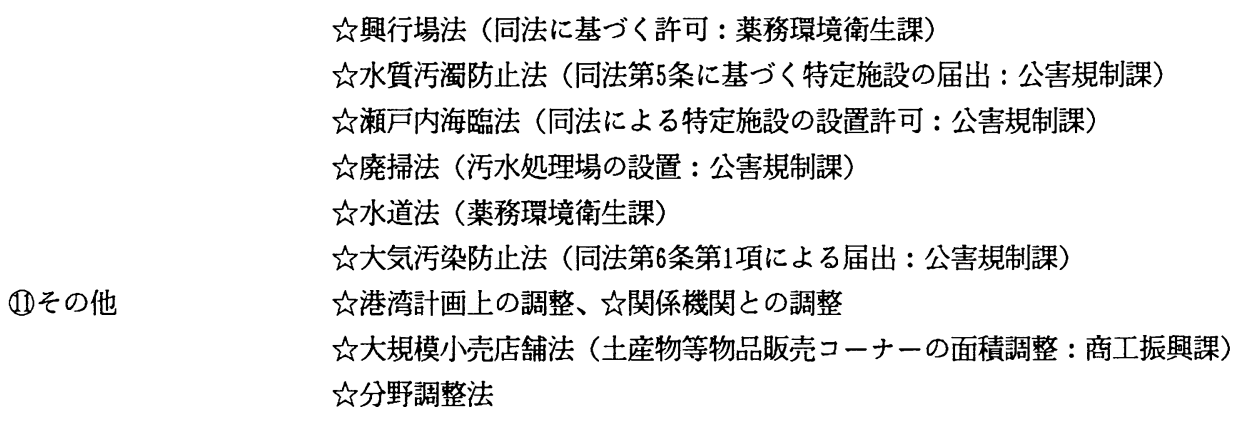

3. 浮体構造物技術マニュアル

(1) 浮体構造物技術マニュアルの目的

浮体形式の港湾の施設及びその係留施設並びにレストラン船その他の係留船の係留施設は、運輸省令で定める 港湾の施設の技術上の基準並びにその解釈及び運用を示した運輸省港湾局長通達（以下、「技術基準」という） に適合するように建設し、改良し、又は維持しなければならない。浮体構造物技術マニュアルは、技術基準に規 定のない細目について規定したものであり、係留船を係留するための港湾の施設又は浮体形式の港湾の施設を計 画し、若しくは設計し、若しくはこれらを審查し、又は、これらの施設を維持管理する際の参考とされるよう編 集されている。

\section{（2）適用範囲}

浮体形式の構造物及びその係留施設のうち次に掲げるものについて適用することができる。

(1) 浮体式係船岸、駐車場船、倉庫船その他の港湾の施設およびその係留施設（ただし、係船浮標、小型のポ ンッーン、浮防波堤、海上貯油基地施設等については、技術基準の内容のほかに特に規定する事項がない ため対象としない）。

(2)レストラン船、博物館船その他の係留船（船舶安全法が適用されるものに限る）の係留施設。

（3）法令の適用

a. 港湾法

港湾において浮体形式の施設を計画する際には港湾法第 3 条の 3 の規定に基づき港湾計画が定められている港 湾にあっては、港湾計画に位置付けなければならない。また、水域を占用して浮体形式の施設を設置する際には、 次に掲げる港湾法の手続が必要である。これに加え、海岸保全区域内にあっては、海岸法第 8 条に基づく海岸管 理者の許可、河川の流水にあっては、河川法第23条に基づく河川管理者の許可が必要となる。またこのほか、都 道府県によっては、条令による水域の占用規制をしている場合がある。なお、漁港については、運輸省令にさだ められたすのを除き、港湾法は適用されず、漁港法が適用される。

(1)港湾区域＼cjkstart港湾法第37条の規定による、港湾管理者の長の許可（港湾隣接区域を含む）

(2)公告区域＼cjkstart港湾法第56条の規定による、都道府県知事の許可

(3)上記以外の水域 港湾法第56条の 3 の規定による、都道府県知事への届出（河川、湖沼、私有水面を含む）

b. 船舶安全法

船舶安全法における「船舶とは」、人が水域において一定の社会的・経済的使命を果すため、水上に浮遊し、 物又は人を積載することができる構造物である。このため、係留船（多数の旅客が利用することとなる以下に掲 げる用途に供する係留船で、2 層以上の甲板を備えるすの又は当該用途に供する場所が閉囲されているすのに限 る）についてる、船舶安全法が適用される。

用途は、劇場、映画館、演芸場または観覧場、公会堂、集会場、キャバレー、カフェー、ナイトクラブ、遊戯 場、ダンスホール、待合、料理店、飲食店、百貨店、マーケット、店舗、展示場、旅館、ホテル、宿泊所、図書 館、博物館または美術館、駐車場、体育館、水泳場その他の運動場、事務所、水族館、展望台である。

\section{（4）位置の選定}

浮体構造施設の位置の選定については、港湾の水域占用許可の用件、船舶航行の影響、周辺環境への影響、風、 波浪潮流など気象海象条件に照し適切に行なう。

（5）浮体構造物の設計

a . 設計の基本的考元方 
浮体構造物の設計にあたっては、原則として「技術基準」によるものとし、設計の際には浮体構造物に要求さ れる機能に対する検討と、安全性に対する検討を行なうすのとする。また、浮体構造物の設計は、設計部位に着 目すれば、係留系の設計と本体構造の設計に大別される。

b. 設計条件

浮体構造物の設計に当たっては、(1)波浪、(2)水位（潮位、高潮、津波）、(3)流れ（潮流、津波流）、(4)風、(5) 地盤条件、(6)上載荷重、(7)地震、漂砂、流水等の自然条件に配慮し、浮体構造物の機能と安全性を検討する。

その場合、設計に用いる風速および波浪の再現期間は浮体構造物の重要性および而用年数を考慮して適切に決 めるすのとする。また、風および波は不規則に変動するので、係留系の特性を考慮して必要に応じて変動風およ び不規則波として取扱う。

\section{c. 浮体の静的安定性}

浮体の安定性は連絡橋の支点反力、積載荷重、区画浸水などを考慮して検討する。

\section{d. 係留浮体の動摇解析}

係留浮体の動摇解析は、外力の不規則性および係留系の非線形を考慮して適切な方法で行なう。とくに、係留 系にごむ防げん材を用いる場合や係留系の変位復元力特性が非対称である場合には、数值シミュレーションによ って係留浮体の動摇解析を行なう。数值シミュレーションの結果は統計処理を行なって、係留浮体の動摇および 係留力の期待最大値を推定する。

\section{e. 浮体の構造強度}

浮体構造物の構造材質としては、P C、R C、鋼やハイブリッド等があるが、材料の特性及び経済性を考慮し て適切に選定する。浮体構造物の構造強度上考慮すべき荷重は、設計条件の項に示した自然条件等によって発生 する荷重等を静荷重（自重、静水圧、浮力など）、動荷重（波力、風圧力、輪荷重、地震力、防衝工反力、係留 力など）に分類し、適切な荷重の組合せを考慮して安全性を検討する。

\section{f 。係留システムの設計}

係留システムの方式は、浮体規模、水深、係留索およびチェーンの材質および長さ、中間シンカーの有無、海 底土質の条件などにより選定される。係留システムの方式は、一般にやや深い水深においてチェーン方式、ワイ ヤ方式、浅い水深において中間ブイ方式、中間シンカー方式、ドルフィン方式、棧橋、係船柱などが用いられる。 また、大水深においては、ワイヤ・チェーンの複合形式が用いられた例あある。チェーン方式、ワイヤ方式では アンカーまたはシンカーを用いる。ドルフィン方式、棧橋、係船柱では、杭、ごむ防げん材、係留索などが用い られる。係留システムの方式は、(1)荷役、乗客等利用者の利用条件に対して安全かつ効率的であること、(2)異常 時の環境条件に対して安全であること、(3)水深、建設費、実績などを勘案して選定する。

本論文においては、係留システムの設計の詳細については割愛するが、浮体構造物設計マニュアルには、チェ ーン方式、ドルフィン・フェンダー方式について、係留系の諸元の決定法が示されている。ドルフィン・フェン ダー方式においては、ドルフィンの地震時の検討が必要であるが、震度法、応答スペクトル法、シミュレーショ ン法による方法が示されている

係留系の細部設計においては、係留チェーンおよび係留索の許容張力、防げん材の許容変形量、アンカーおよ びシンカーのはちゅう力ならびに安全率、ドルフィンの設計荷重などが示されている。

g. 浮体構造物の維持管理

浮体構造物は、浮体本体が浮遊していること、その構成が浮体、係留施設等の複合したすのであることから、 万一構成要素が機能を損うと施設全体の使用性、安全性に係わることになり、また、浮体構造物の構成要素は動 摇等のため損耗、疲労等を生じやすく、一般の港湾構造物に比べて維持管理に特に注意する必要がある。主要な 維持管理の項目は以下のとおりである。

(1)係留索の強度。特に、劣化特性について十分注意を要する。

(2)チェーンの腐食および摩耗。

(3ここむ防げん材の繰返し圧縮特性、経年変化、クリープ等による圧縮特性の変化。

(4)浮体本体の腐食、コンクリートのひびわれなど。

\section{4. あとがき}

ここに、事例を示したように、近年活発化する沿岸開発プロジェクトの中で、浮体構造物の採用す増加してき ていて、技術マニュアルの整備が強く要望されてきている。ここに示した浮体構造物技術マニュアルはこのよう な状況に対応するために、（財）沿岸開発技術研究センターが、学識経験者および関係機関の委員により構成さ れる「浮体構造物技術マニュアル検討委員会」において慎重なる審議がなされている。審議においては、横浜国 立大学合田良實教授はじめ委員各位、運輸省港湾局および海上技術安全局のご指導を得た。関係各位に深甚なる 謝意を表する次第である。 